\title{
Un mito en piedra: La sexualidad en el contexto religioso de la Iglesia
}

\author{
M. a Ángeles Menéndez GutiérRez *
}

\begin{abstract}
RESUMEN
ABSTRACT

Investigación sobre la temática

This investigation is about the sexual theme of the Romanesque sexual en la escultura románica de la primitiva Castilla, en la que se aborda

un estudio iconográfico de aquellas representaciones que, por su propio carácter, se apartan del marco bíblico, entrando de lleno en esa iconografía denominada obscena, reunida en el marco religioso de la iglesia por toda una serie de festividades que las lleva

a reactualizar todo un ciclo natural, cósmico y genésico, en íntima relación con las creencias de unos monjes y un pueblo llano, apegados a sus antiguas tradiciones, que continuaban

manteniendo $y$ aún celebrando sus ancestrales ritos relacionados con los ciclos vitales. sculpture in the early "Castilla". It is an iconographical study of those representations separated from a Biblical field, that one knowing as obscene iconography. This obscene iconography is located at the religiouse environment of the church and it is connected thanks to several festivities. So a natural, cosmic and genetic cycle is updated again because it is connected intimately with some monks and people's believes. People, devoted to ancient traditions, kept and celebrated their ancestral rites related with life cycles.
\end{abstract}

\section{INTRODUCCIÓN}

Abordar un trabajo con rigor de la temática que nos ocupa no es tarea fácil, teniendo en cuenta la iconografía a tratar y la valoración e interpretación que hasta ahora se le ha dado, pues, ante el carácter moralizador y

\footnotetext{
* Centro Asociado DENIA. UNED.
} 
evangelizante de la escultura románica como un arte de prensa y propaganda, se quiso ver en estas representaciones toda una serie de manifestaciones del mal, y es así como a la hora de tratarla, todas las consideraciones aluden siempre a lo mismo: a la representación del pecado, sin más.

$Y$ es que, hasta ahora, esas representaciones contempladas a la luz de los escritos de muchos Padres de la Iglesia, no podían ser otra cosa que la representación del pecado en general, y de uno muy en particular: la lujuria.

No podemos olvidar tampoco la corriente de ascetismo que imperaba en la época medieval, y que la Iglesia de Roma invitaba a seguir como camino de salvación, perfección y gloria. Es por eso, y bajo ese prisma, por lo que las imágenes de temática sexual sólo podían simbolizar el pecado. Pero se llega a esa conclusión solamente teniendo en cuenta que esas clases de usos y costumbres fueron sucesivamente criticadas, duramente recriminadas, condenadas y prohibidas. Que existían y eran de uso generalizado, nadie lo pone en duda. Las mismas prohibiciones en sucesivos Concilios, las mismas arengas condenatorias de tantos y tantos Santos Padres medievales en sus escritos, dirigidos a toda la Cristiandad, nos lo atestiguan.

Podríamos aceptar esta explicación y admitir esta interpretación, si nos conformamos con una postura unilateral y cómoda. Pero, si somos consecuentes con nosotros mismos, no podemos acallar una serie de interrogantes que surgen ante su contemplación y ante lo dicho hasta ahora en torno á ellas:

Primero, si esa clase de usos y costumbres estaba tan generalizada tanto entre el clero como entre la población civil, ¿por qué sólo aparece esa iconografía dirigida a ciertos grupos, en un ámbito muy determinado de cada país en el que nos la encontramos, y con una cronología muy precisa?

Segundo, si cada programa iconográfico, como estamos acostumbrados a ver en el románico, tiene siempre en esencia un mensaje didáctico, y se nos manifiesta a través de toda una serie de secuencias y programas del Juicio Final, en donde todo está polarizado hacia el bien o hacia el mal a través de esa lucha entre vicios y virtudes, ¿dónde está aquí esa lucha?, ¿dónde está aquí esa polarización?, ¿dónde están esas secuencias?

Tercero, si siempre nos encontramos a un Dios justiciero que premia a los buenos y castiga a los malos, y a los justos en la contemplación de Dios, mientras los pecadores son víctimas de toda clase de horrores en el infierno, ¿dónde se representa aquí el premio o castigo?, ¿dónde el cielo o el infierno?

$Y$ así como éstas, podrían ir surgiendo toda una serie de preguntas que no podemos acallar con una sola contestación: es la representación del pecado de la carne. 
No negamos que dentro de otro contexto y otro tiempo, algunas de estas imágenes no sean el símbolo de la lujuria y de algunos vicios duramente criticados a través de imágenes procaces dentro de una corriente moralizante o puramente costumbrista, pero no creemos que éste sea el caso en nuestro contexto, tanto topográfico como cronológico.

Creemos pues, que estas representaciones no son símbolo del pecado, ni tienen intención moralizadora. Son, en nuestra opinión, la consecuencia de la manera de pensar y vivir de unas gentes en un momento muy concreto del medievo, y en un ámbito geográfico determinado. Forman todas ellas un programa o ciclo iconográfico muy definido, en donde cada una aporta una significación concreta que alcanza su máxima expresión en el conjunto, pero en ningún momento relacionadas con los vicios de la carne - los bajos instintos. Esta iconografía que venía denominándose erótica u obscena, forma parte de la representación de todo un ciclo vital: nacimiento-muerte-resurrección, compendio de creencias y mitos latentes en la conciencia del pueblo y en un sector de la Iglesia, y que todavía aún siguieron manteniendo en un estadio inmediatamente anterior a la labor moralizadora cluniacense en el ámbito que nos ocupa.

Llegar a todas estas conclusiones no fue tarea fácil, sino el resultado de cinco años de investigación, y después de ir constatando y analizando tosas aquellas representaciones antropomorfas de implicaciones hoy por hoy obscenas, que, por su propio carácter, se apartan del marco bíblico y nos trasmiten otro tipo de mensaje distinto al de la Iglesia oficial. Éstas se caracterizan por toda una serie de rasgos iconográficos muy significativos y privativos de ellas, que no tienen nada que ver con iconografías posteriores, y no aparecen arbitrariamente, sino dentro de un contexto muy determinado. En él nada nos habla de pecado, pues, al tratar cada modalidad por separado, vimos como cada una de ellas representa: la procreación, muerte y resurrección, todo ello dentro de un contexto festivo y muchas veces litúrgico.

\section{CRONOLOGÍA, TEMÁTICA Y ESTILO}

Analizadas las iglesias dentro del ámbito geográfico de la primitiva Castilla ${ }^{1}$, se puede llegar en primer lugar a unas conclusiones generales

\footnotetext{
Ver: MENÉNDEZ GuRIÉRREZ, Ma A.: Representaciones antropomorfas de carácter profano en el Románico hispano. Tesis Doctoral (inédita). U.N.E.D. Diciembre 1995. T. II. Apéndices, [págs. 942 a 957], en donde se da una relación de todas las iglesias románicas que existen en el ámbito de la primitiva Castilla, con una reseña de su cronología e interés iconográfico.
} 
claras: Todas ellas tienen una cronología que va desde los primeros años del S. XII, e incluso finales del XI, hasta ya entrado el S. XIII algunas de ellas. En aquellas de los últimos momentos, en que la nueva manera de hacer goticista es palpable, la ausencia de iconografía se hace patente. Con aquellas pertenecientes al S. XII se pueden hacer dos grupos. Al primero pertenecerían las que indudablemente se pueden catalogar dentro de la primera mitad de dicho siglo; en el segundo se localizarian aquellas cuya cronología corresponde a la segunda mitad del mismo. Tal división no corresponde sólo a motivos puramente cronológicos, sino que, las diferencias iconográficas y estilísticas también son palpables.

Por lo que respecta a su iconografía, en las primeras se observa una falta absoluta de temática religiosa, es decir, de escenas sacadas del Antiguo y Nuevo Testamento, o pertenecientes al santoral cristiano, siendo en ellas en donde aparece toda esa serie de representaciones en donde la sexualidad juega un papel importante, y que hoy en día vienen denominándose obscenas. No pasa lo mismo en el segundo grupo, en el que la temática religiosa, en mayor o menor medida, es constante. Otro dato importante es que en aquellas cuya duración de obra traspasa las fronteras de esa primera mitad, o que sufrieron añadidos posteriores, existe la yuxtaposición de las dos temáticas, y en algunas, cuya cronología está a caballo entre uno y otro momento, esa temática denominada obscena empieza a ser tratada de diferente manera.

En cuanto a su estilo, se ve claramente como la influencia francesa no empieza a sentirse hasta esa segunda mitad de siglo, y por otra parte, el llamado primitivismo de talla que muestran las de la primera mitad, se convierte en virtuosismo en la segunda, teniendo que tanto iconografía, como temática y estilo, marcan una clara diferenciación entre las mismas. Esto nos da pie para afirmar que nos encontramos con una escultura a caballo entre lo que de prerrománico ha llegado hasta nosotros y la posterior románica que sigue las preceptivas impuestas por Cluny, y con una cronología que queda limitada a la primera mitad del siglo XII, extendiéndose por un marco geográfico apartado de las grandes vías de influencia cluniacense, al Norte del Camino de Santiago.

\section{LA ICONOGRAFÍA Y SUS FUENTES}

La iconografía que encontramos en la plástica abarcada por nuestro estudio, podría clasificarse en una serie de apartados en función de los personajes y las actitudes que éstos adoptan. Hay que tener en cuenta para ello q $\lambda$ e no partimos de ninguna idea preconcebida, ni de clasifi- 
caciones previas existentes en la bibliografía consultada. Es por ello que dicha clasificación es susceptible de mejoras y variaciones, a las que pueda llevarnos el conocimiento de nuevas fuentes y referencias artísticas.

Según nuestra propia clasificación, las modalidades que hallamos en esta plástica, son las siguientes: Ostentación de ambos sexos. Coitos o acoplamientos. Embarazos y partos. Los enmascarados. El mundo de la juglaría. Otras formas de sexualidad. El Monstruo Andrófago.

\section{III.1. Ostentación de ambos sexos}

Es un tipo de iconografía que se repite constantemente en estas iglesias, y muy poco analizada y estudiada, a no ser para clasificarla, en términos demasiado generales, como la representación del pecado de la carne.

Si nos atenemos a su iconografía, vemos como estas representaciones están aludiendo a algo concreto, siendo la ostentación de un sexo u otro el tema principal.(fig.1 y fig.2) Todo el énfasis está puesto en ello, los órganos genitales se encuentran deliberadamente exagerados, y se agrandan adquiriendo proporciones inusitadas de indudable contenido simbólico ya a primera vista.

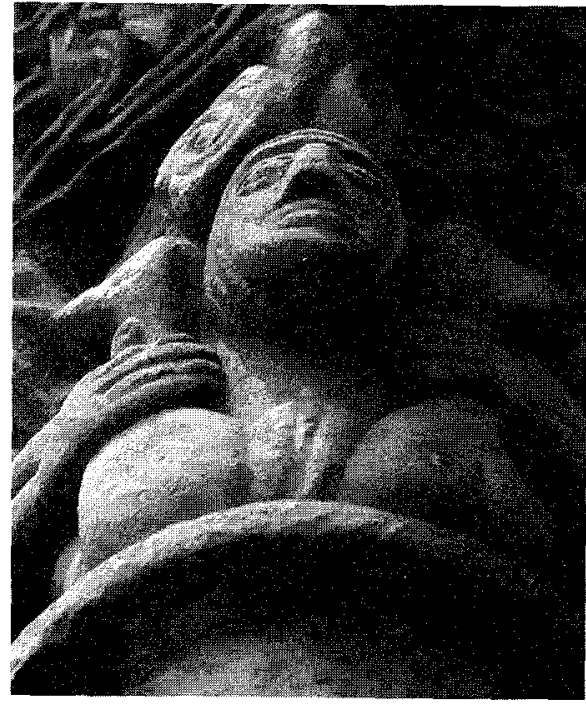

Fig. 1. San Pedro de Cervatos: Capitel Izquierdo de la primera ventana del ábside.

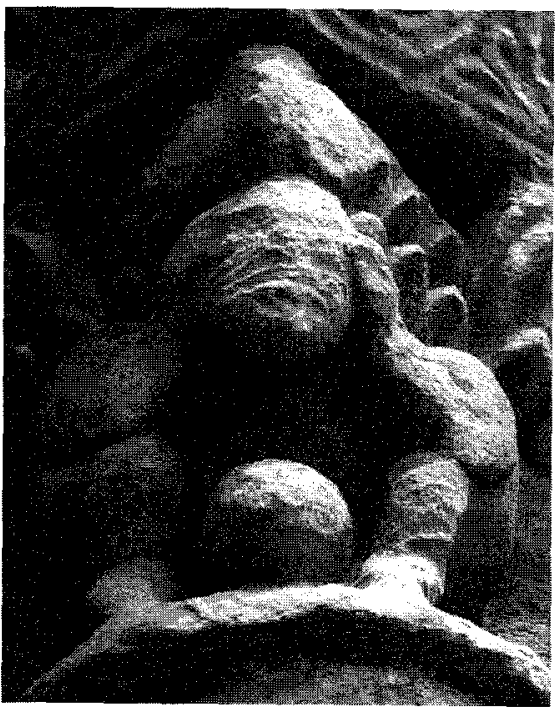

Fig. 2. San Pedro de Cervatos: Capitel derecho de la primera ventana del ábside. 
Si nos atuviéramos a las fuentes que hasta ahora han sido consultadas a la hora de valorar esta iconografía, y las afrontáramos desde el mismo punto de vista, no sería de extrañar que llegásemos a las mismas conclusiones, es decir, que toda esta iconografía no es ni más ni menos que la denuncia de uno de los pecados más comunes en aquella época, como era el de la lujuria, denunciado por los Santos Padres, y que era preciso erradicar. Pero al enjuiciar éstas desde otros puntos de vista, y rastrear otras, que son precisas tener siempre en cuenta, hemos llegado a otra serie de conclusiones que nos apartan completamente de la teoría tradicional que ha venido imponiéndose hasta ahora.

Los escritos de muchos Padres de la Iglesia y las actas de los Concilios nos demuestran que, lo que en estadios anteriores tenía una valoración positiva y estaba vinculado a cultos y ritos de fecundidad, pasa a ser considerado como pecado, pero también valorado de distinto modo por los diversos estamentos de la sociedad, puesto que, si desde la antigüedad hasta el S. $\mathrm{XV}$ las denuncias son constantes, estas mismas denuncias nos ponen en conocimiento de que tales prácticas seguían realizándose, e incluso asociadas a los mismos fines, es decir, íntimamente ligadas a ritos de fecundidad, como nos lo corrobora el carácter que adquieren algunos santos a los que se rinde culto, y perfectamente bien visto y admitido por esa Iglesia que continuamente prohibía antiguas prácticas relacionadas con el culto a "Príapo", pues perviven en determinadas tradiciones ciertos rituales fálicos, asociados ahora al poder milagrero de algunos santos patronos, en los que sus características itifálicas nada tienen de erótico u obsceno, muy por el contrario, el carácter fecundante es patente ${ }^{2}$. Todo esto viene a demostrarnos que, a parte de que existiera en toda aquella época una encarnizada lucha para desarraigar determinadas costumbres, ciertas prácticas y creencias son asimiladas por la iglesia ortodoxa, llevándonos hacia un sincretismo en el que queda patente que los órganos genitales, tanto masculinos como femeninos, eran considerados como principio fecundante y generador.

Y es que la tradición pesa mucho en las mentes de aquellas gentes más apegadas a la tradición popular, en donde esa mujer, impúdica para la ascética del cristianismo medieval, es antes que nada el principio de la vida, heredera de aquella Seela-na-gig ${ }^{3}$, que en Irlanda era la diosa madre de-

\footnotetext{
2 Gaignebet, C. y Lajoux, J. D.: Art profane et religión populaire au moyen âge. París. Presses Universitaires de France, 1985, [págs.: 192-193].

3 SHARKEY, J.: Misterios celtas. Madrid. Editorial Debate, S.A. 1989, [pág.: 30]. Sobre Seelana-gig, ver también: DEverAux, G.: Baubo. La vulva mítica. Barcelona. Icaria Editorial, S.A. 1984, [págs.: 97 a 99]. Es preciso hacer hincapié sobre el paralelismo que existe entre esta idea y el simbolismo del monstruo andrófago. Champeaux y Sterckx, dependiendo del tema imaginario
} 
voradora del simbolismo celta, donante y privadora de la vida, y que allí pasa al románico con una iconografía muy semejante a ésta que vemos en nuestra plástica.

De este modo, esa mujer impúdica, obscena, que levanta las piernas enseñando sus partes más intimas, cobra otra valoración que nos aparta de la corriente misógina que imperaba en la época, y nos acerca en cambio a la valoración que de la mujer se hacía en otros círculos desvinculados de la iglesia ortodoxa, valoración que nos pone de manifiesto algunos textos gnósticos: "Yo soy el principio y el fin. / Soy la honrada y la escarnecida. / Soy la puta y la santa. / Soy la esposa y la virgen. / Soy la novia y el novio, / y es mi esposo quien me engendró. / Soy conocimiento e ignorancia... / Soy necia y sabia... / Soy aquella a quien llaman vida [Eva] / y vosotros la habéis llamado muerte." 4 .

Por lo que respecta al sexo masculino, tenemos que pasa otro tanto de lo mismo, pues de la importancia concedida al falo como elemento fecundador, son muchos los escritores de la Antigüedad que nos dejan constancia de ello, viendo como nos hablan entre otros: Jámblico, Diodoro de Sicilia y Plutarco. Por el primero sabemos que los griegos consagraban muchos falos a la primavera, como muestra de que los dioses daban al mundo la fuerza generadora ${ }^{5}$. Diodoro de Sicilia escribe que el falo del macho cabrío se adoraba como personificación del principio de todos los seres, ya que era instrumento de generación, y por él daba la naturaleza nacimiento a todos ellos ${ }^{\circ}$. Plutarco también nos cuenta que Osiris era figurado de forma itifálica para representar su poder generador y fecundante?

Que era considerado en algunos casos como una auténtica divinidad, nos lo constata Horacio, cuando en una de sus famosas sátiras nos lo manifiesta claramente al hacer hablar a un tronco de higuera:

del engullidor, lo consideran dentro de la misma cadena de símbolos, como el útero que concibe y da a luz. Champeaux, G. y SterckX. D.S.: Introducción a los símbolos. Vol. 7 de la serie Europa Románica. Madrid. Ediciones Encuentro. 1989, [pág.: 340].

${ }_{4}$ Texto en: PAgels, E: Adán, Eva y la Serpiente. Barcelona. Editorial Crítica. 1990, [pág.: 106].

KAYDEDA, J. M: Los rituales fálicos. Jávea. Mundibook S.A. 1989, [pág.: 25].

Ibídem, [pág. 27]. Supone esta obra una recopilación bastante completa de toda una serie de rituales y creencias, que desde la antigüedad se fueron sucediendo en distintas religiones y culturas, con respecto a los órganos reproductores masculino y femenino, por lo que en toda ella podemos encontrar toda una serie de datos, tanto escritos como plásticos, que atestiguan este carácter procreador y fecundante.

García VAldés, M.: Plutarco. Obras morales y de costumbres. "Sobre Isis y Osiris». Madrid. Editorial Akal S.A. 1987, [pág.: 97]. 
«Yo era un tronco de higuera, cuando un obrero, dudando entre hacer un banco o un príapo, decidióse al fin, y en lugar de ser un banco fui un dios ${ }^{8}$.

\section{III.2. Coitos o Acoplamientos}

Al igual que las otras, su descripción iconográfica no deja lugar a dudas, pues vemos como nos están aludiendo a algo concreto, como es el momento de la penetración (fig. 3), captado en todo su realismo. Estamos pues de nuevo ante una iconografía que, si bien a primera vista pudieran estar aludiendo de nuevo al mundo del pecado de la carne, por las características que muestra ésta, y por como es tratado este mismo tema en momentos inmediatamente posteriores, ésta, sin duda, nos está remitiendo al concepto de la procreación, lo que nos introduce en una esfera distinta.

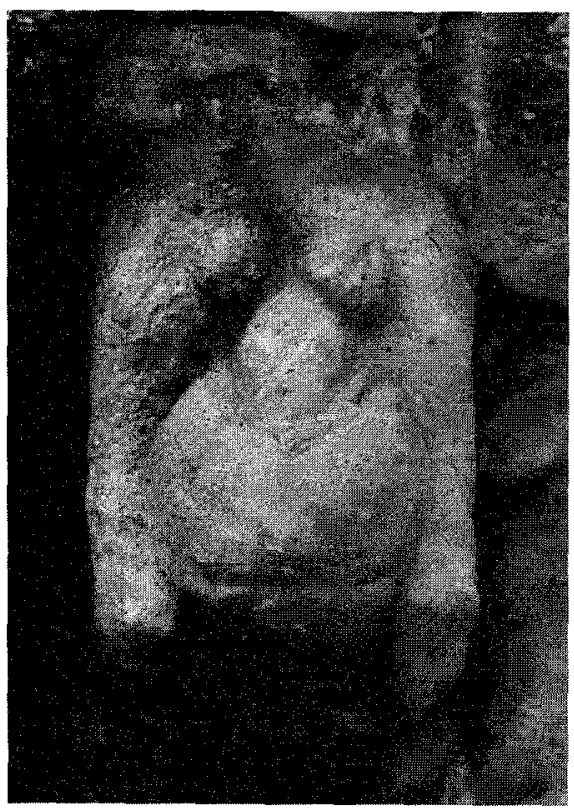

Fig. 3. San Pedro de Cervatos: Canecillo no V del tejaroz de la portada sur.

8 Texto en: KaydeDA, J. Mª: Op., cit., [pág.: 68]. 
Y es que, como tuvimos ocasión de corroborar por las fuentes, el acto de la procreación no solamente no era considerado pecado, sino que incluso no era algo extraoficial a la Iglesia, pues incluso vimos como existían toda una serie de vigilias con motivo de las fiestas de determinados santos patronos de marcado carácter fecundante ${ }^{9}$, en las que el lugar sagrado de la iglesia era utilizado como lugar de reunión de hombres y mujeres que pasaban toda la noche cantando, bailando y cometiendo todo tipo de profanidades como nos comunica Don Juan Manuel, ${ }^{10}$ y como nos quedó ya constatado por el concilio Aurelianense del año $533^{11}$. Actos que incluso perduraron hasta el S. XVI en que el acto sexual era uno de los componentes del risus paschalis, en el que, y según Jacobelli, se ocultaría una realidad sagrada bajo una forma populachera y vulgar cargada de condicionantes culturales, de la misma forma que en el Cantar de los Cantares nos encontramos expresado de una forma poética la relación entre Dios e Israel a través de la utilización de todo tipo de términos propios del goce sexual ${ }^{12}$.

$Y$ es que, dentro de la cultura popular, en la que no cabe duda que nos movemos, el acto del coito tiene otro carácter, como demostró Mijail Bajtin, siendo el acto carnal uno de los tres actos esenciales de este gran cuerpo popular que tenía una visión diferente del mundo, del hombre y de las relaciones humanas, y que en actos como el coito, expresado con toda su materialidad inmediata, era en donde los cuerpos parecían revelar su esencia como principio en crecimiento que traspasaba sus propios límites ${ }^{13}$, quedando constatado a través de nuestra iconografía en esas mujeres en estado de gestación que lleva consigo el nacimiento de una nueva vida; pudiendo observar este hecho en todos esos alumbramientos o partos, característicos también dentro de nuestra plástica.

Estamos, pues, ante la representación de dos cuerpos que suponen dos eslabones en la evolución de la especie, observados en su punto de unión, cuando uno penetra en el otro, estamos pues ante un acto generador, tal como lo defiende Clemente de Alejandría cuando opina que la relación sexual no es pecaminosa, sino una parte de la creación original de Dios, y por encima buena, pues los que procrean no pecan, sino que: «cooperan con Dios en su obra creadora" ${ }^{14}$.

Galgnebet, C. y Lajoux, J.D.: Op., cit., [pág.: 192].

10 Menéndez Pidal, R.: Poesía juglaresca y juglares. Madrid. Editorial Espasa Calpe, 1969, [pág.: 58].

JACOBELLI, M.C.: Risus Paschalis. Barcelona. Editorial Planeta, 1991, [pág.: 59].

lbídem, [págs. 86 a 90$]$.

13 BAJTIN, M.: La cultura popular en la Edad Media y el Renacimiento. Madrid. Alianza Editorial, 1989, [pág:: 30].

${ }_{14}$ Ver: PAGELS, E.: Op., cit., [pág.: 57]. 


\section{III.3. Embarazos y partos}

Las representaciones del primer grupo son todas ellas de una iconografía muy similar, pudiendo decir sin miedo a equivocarnos que lo que en ellas se representa es a la mujer embarazada mostrando una actitud muy típica, como es la de llevarse las manos a ambos lados de la barriga y mirar su abultado vientre, llamando de esta manera la atención del espectador sobre el estado en que se encuentra (fig. 4). Parece que se tratan todas ellas de mujeres casadas, pues cubren su cabeza con la toca característica que las diferencia. El desnudo es constante, no dando muestras de cubrir su cuerpo con ninguna vestimenta. En el segundo, incluimos todas aquellas en que el momento del alumbramiento es patente, siendo, sin lugar a dudas, una escena de parto, captada justamente en el momento en que la criatura asoma su cabeza al mundo exterior (fig. 5).

Nos encontramos, pues, sin duda, ante dos modalidades iconográficas que, si bien nadie se ha preocupado de ellas al abordar esta plástica, no obstante, al rastrear otras fuentes, vemos como esta iconografía cobra vida.

Vuelven a ser éstas la existencia de toda una serie de festividades como la de Santa Brígida, heredera de una antigua diosa del fuego y de la

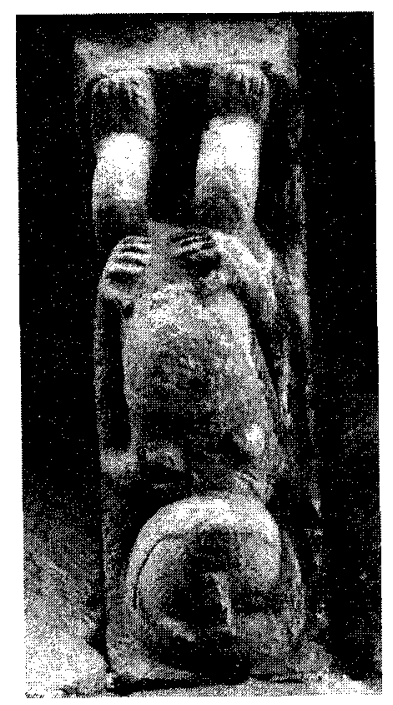

Fig. 4. Revilla de Santullán: Canecillo $n^{\circ} \mathrm{V}$ del ábside.

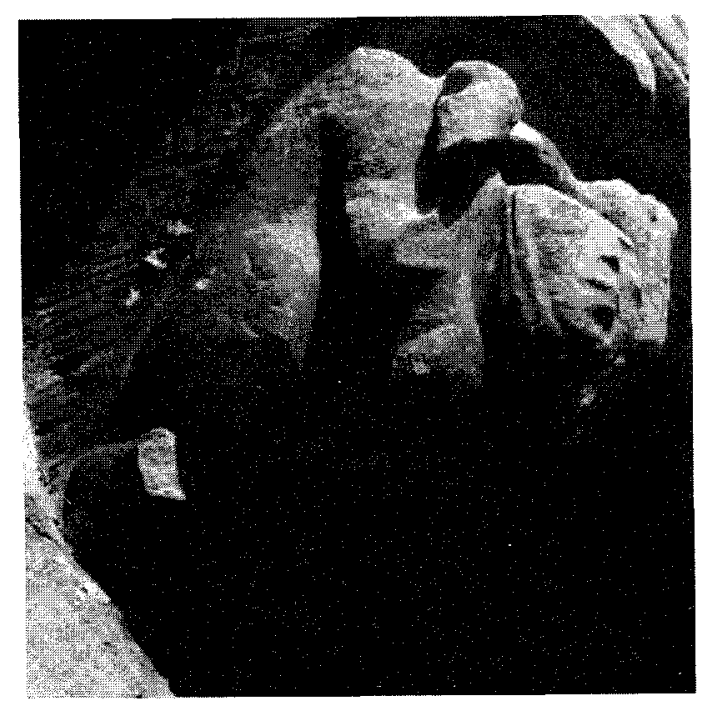

Fig. 5. Villanueva de la Nía: Canecillo $n^{\circ} \vee$ del ábside. 
fecundidad, y en la que en algunos lugares salía un joven disfrazado que representaba a la Santa, y simulaba un parto ${ }^{15}$.

Semejante hecho tenía lugar también durante el transcurso de muchas mascaradas en la región vasca y navarra, relacionadas con el primero de año y con el Carnaval ${ }^{16}$. En Asturias, otra mascarada muy característica era la de los «Guirrios», en la que una vieja, la «Filaora», hilaba, se fingía enferma y paría ${ }^{17}$. Un mayor contenido ritual, no cristiano, se quiere ver en la mascarada de Campo de Caso (Asturias), en la que un hombre disfrazado de vieja, "Marica», acompañado de otro que figuraba como su marido, aparecía en un estado de preñez avanzado. La vieja fingía los dolores del parto, y frente a una hoguera se figuraba éste; al final Marica paría un gato ${ }^{18}$.

No cabe duda de que se coincide más en el fondo qúe en la forma, pero, como dice Caro Baroja, no se puede olvidar que: «(...) los intereses dominantes de la sociedad que celebró unas fiestas se ajustan a un esquema muy parecido al que mantuvo una sociedad que había cambiado de credo (...), pero que seguía trabajando, amando, creciendo y multiplicándose de modo igual» ${ }^{19}$.

También para Mijail Bajtín: «(...) es en la cultura popular, en sus fiestas, en donde mejor podemos rastrear estos acontecimientos, pues, todas las imágenes de la fiesta popular fijan el momento del devenir y del crecimiento. En todas partes el acento está puesto en la reproducción: preñez, alumbramiento, virilidad, y esto es, porque la cultura popular de aquel tiempo tenía una visión del mundo y del hombre completamente distinta a la que posteriormente imperará en nuestra época» ${ }^{20}$.

\section{III.4. Los Enmascarados}

Son éstos formas monstruosas que aparecen en la plástica, y si siempre fueron interpretadas como demoníacas y alusivas al mundo infernal, no fue ni más ni menos porque siempre fueron vistas bajo un mismo prisma y sin ser diferenciadas entre sí. Pero como podemos comprobar, estas

\footnotetext{
15 Del Olmo García, A. y Varas Verano, B.: Románico erótico en Cantabria. Palencia,1988, [pág.: 96].

16 CARO BAROJA, J.: El carnaval. (Análisis histórico cultural). Madrid. Ediciones Taurus. 1985, [págs.: 204-205].

Ibídem, [pág. 218].

18 Ibídem, [pág. 221].

19 Ibídem, [pág. 151].

20 BaJtin, M.: Op., cit., [págs.: 219 a 222].
} 
formas que aparecen en nuestra plástica son sin lugar a dudas hombres enmascarados, (fig. 6) y no tienen nada que ver con seres fabulosos, medio humanos medio animales, no representando tampoco todos 10 mismo. Esto nos llevó a rastrearlos a través de otro tipo de fuentes que nos hicieron interpretarlos de una manera muy diferente, y ligados a alguna festividad religiosa.

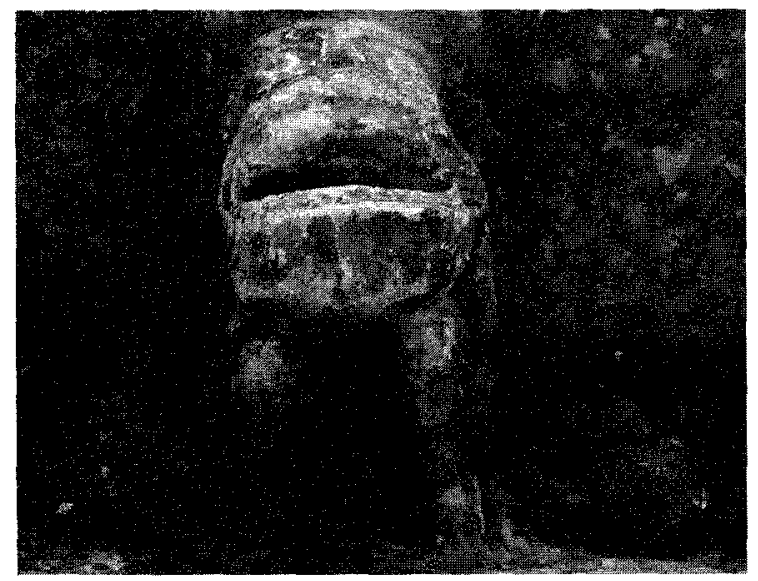

Fig. 6. San Pedro de Cervatos: Canecillo no $\mathrm{N}$ del tejaroz de la portada sur.

Estos enmascarados pueden tener su origen en la costumbre de cubrirse el rostro con máscaras, presente ya en las cuevas prehistóricas, continuándose como una constante a lo largo de toda nuestra civilización. Así lo vemos en la antigua tradición religiosa precristiana de Roma, más concretamente en las Calendas de Enero, las Saturnalia, las Brumalia y Matronalia, recogiendo esta tradición Tertuliano a comienzos del S. III, Libanio (S. IV), San Agustín (354-430), San Juan Crisóstomo (344- 407), San Pedro Crisólogo (406-450) ${ }^{21}$ y San Isidoro de Sevilla. Según éste, en ciertas festividades los hombres: «(...) se disfrazan a modo de fieras, y otros toman aspecto mujeril», ${ }^{22}$ hechos que también relata a finales del $S$. VIII San Bonifacio, obispo de Maguncia, que refiere como los cristianos celebran esta fiesta de las Calendas de Enero, así como las otras festividades paganas citadas ${ }^{23}$. De aquí a su representación en la plástica que estudiamos sólo hay un paso.

\footnotetext{
1 Caro Baroja, J.: Op., cit., [págs.: 168 a 173].

Texto en: lbídem, [pág.: 172].

lbídem, [pág.: 173].
} 
Es por ello por lo que la Iglesia no va a tener más remedio que cristianizar algunas de ellas, pues incluso vemos como fueron los mismos Sumos Pontífices de Roma los que recomendaron a sus sacerdotes que predicaban la nueva religión, que no destruyesen los antiguos lugares de culto, sino que cristianizasen los dioses y usos paganos. Así lo tenemos en la carta «Historia gentis anglorum» (I. 30) del Papa San Gregorio Magno a Beda el Venerable con ocasión de su predicación en Inglaterra, en la que se recomienda dicha política sincretista.

Pasarán así estos enmascarados, junto con las demás representaciones obscenas que nos ocupan, a tomar parte activa en ciertas representaciones cristianas, con unas funciones y significaciones precisas: la encarnación y personificación de ciertos espíritus terroríficos con el fin determinado de expulsar periódicamente a los espíritus malignos, generalmente una vez al año, y contribuir así, de esta manera, a la protección de la reproducción de las especies, teniendo también un carácter purificatorio y de renovación del ciclo cósmico, siendo herederos de aquellos de la Antigüedad, así como San Cosme, San Damián, San Blas o San Greluchon, heredan las características propiciatorias de la fecundidad del romano Príapo.

Así pues, en el ambiente religioso de la época, unos vienen a sustituir a los anteriores, y si bien la Iglesia pudo marginar lo que a primera vista tenían más de pagano, todavía era muy pronto para poder desvincularlos de su contenido y manifestaciones.

\section{III.5. El mundo de la juglaría}

Eran los juglares (fig. 7) elementos obligados en ciertas festividades muchas veces de carácter religioso, así, en la tradicional «Fiesta de Los Carros» figuraban obligatoriamente en la procesión solemne todo tipo de gente disfrazada, jóvenes efectuando danzas más bien sensuales, y al final del cortejo, en el que también tomaba parte el sacerdote con la hostia, aparecían los coches decorados con cómicos disfrazados ${ }^{24}$.

El concilio Avernionense de 1209 lo dice también claramente: «Queda establecido que en las vigilias de los santos no se harán en las iglesias ni danzas de saltimbanquis, ni gestos obscenos, ni bailes, ni se recitarán poesías de amor o canciones amorosas" ${ }^{25}$. Del mismo modo, es a través de

${ }^{24}$ BaJtín, M.: Op., cit., [pág.: 206].

25 En: JaCOBELli, M.C.: Op., cit, [pág.: 56]. 


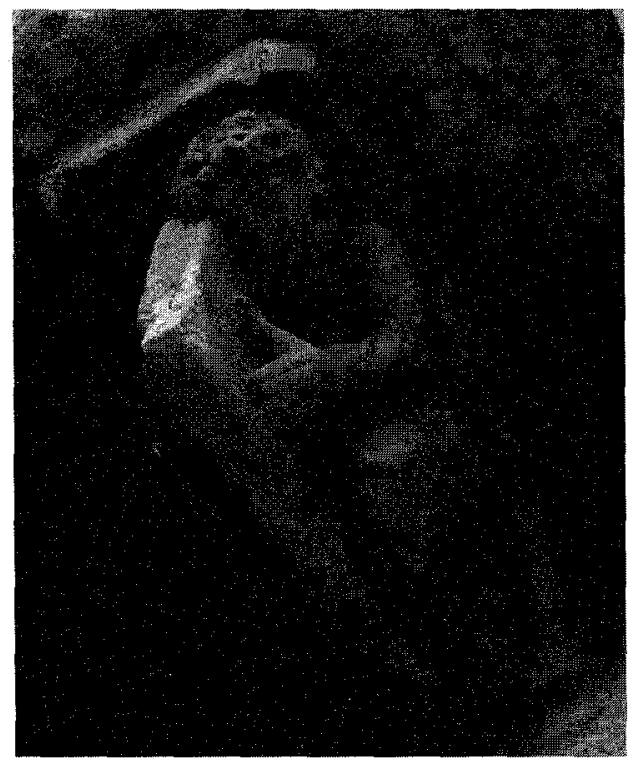

Fig. 7. San Pedro de Cervatos: Canecilo no /l del ábside.

los concilios de Valladolid (1228), Toledo (1324), y Aranda (1473), ${ }^{26}$ por los que nos llegan similares prohibiciones.

Así pues, todo esto nos está hablando de ciertos tipos de juglares, espectáculo obligado en ciertas ceremonias religiosas, y que juntamente con toda esa otra iconografía a la que acompañan, toman parte en representaciones con motivo de algún acto religioso. En conclusión podríamos decir que, más que emparentarnos con una temática juglaresca, en su acepción tradicional, nos están introduciendo en otro tipo de temática festiva, emparentada incluso algunas veces con la liturgia.

Por otra parte, en nuestra plástica existe también un grupo muy característico que hasta ahora no se tuvo en cuenta, y que aparecen tocando distintos instrumentos, diferenciándose claramente de los anteriores citados, por ir desnudos. (fig. 8) A éstos, por la forma con que tienen de cubrirse la cabeza, los hemos identificado con clérigos juglares, son los que en literatura Menéndez Pidal distingue como un grupo afín al juglar, llamados también escolares vagabundos, los clerici ribaldi, máxime qui di-

${ }^{26}$ Sebastián López, S.: Iconografía Medieval. San Sebastián. Editorial Etor, 1988, [págs.: 448$449]$. 


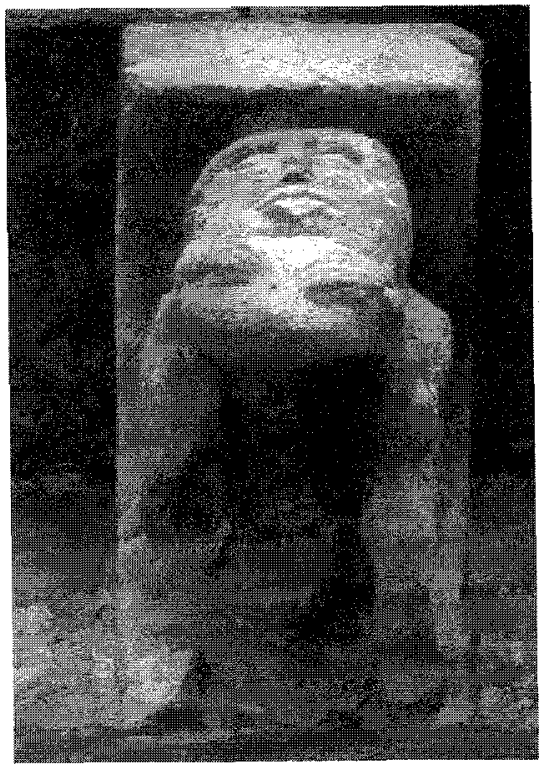

Fig. 8. Bárcena de Pie de Concha: Canecillo no XVII del ábside.

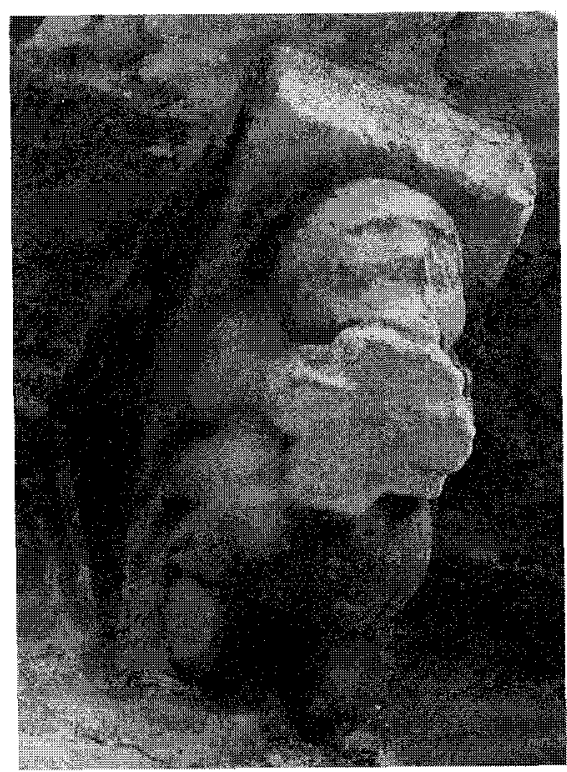

Fig. 9. San Pedro de Cervatos: Canecillo no III del muro sur.

cuntur de familiae Goliae, ${ }^{27}$ a los que ya a principios del $\mathrm{S}$. $\mathrm{X}$ el arzobispo de Sens manda rapar para borrarles así la tonsura clerical ${ }^{28}$. Sería pues un grupo afín a los goliardos, a los que el concilio de Tréveris de 1223 prohibía cantar versos durante la misa (fig. 9), el Sanctus, y el Agnus Dei ${ }^{29}$. En fin, que en nuestra plástica aparecen toda serie de clérigos realizando distintas actividades fuera completamente de la ortodoxia que la iglesia de Roma intenta imponer, como queda constatado también en Las Partidas cuando se prohibía a los clérigos hacer juegos de escarnio ante el público, y por el concilio de Tarragona que un siglo después volvía a condenar a aquellos que ejercían de juglares y de mimos, lo mismo que las Constituciones Sinodales de Urgel excomulgaba a los clérigos de órdenes que danzaban en público haciendo lubricio de su cuerpo ${ }^{30}$, teniendo constancia de que, todavía en el S. XVI, son admitidas en la iglesia, con motivo de la misa de Pascua de Resurrección, toda serie de chanzas,

27 Menéndez Pidal, R.: Op., cit., [pág.: 28].

28 lbídem.

29 Ibídem.

so Ibídem. 
tales como, nos enumera Jacobelli: «(...) palabras lascivas; ofensas al pudor; imitación del acto sexual; comportamiento onanista o bien (quizá) homosexual» ${ }^{31}$.

\section{III.6. Otras formas de sexualidad}

Es muy normal encontrar dentro del contexto que nos ocupa, toda serie de representaciones que, por la actitud que muestran los personajes representados, y según la ortodoxia cristiana, podemos calificar a primera vista de degradantes, pero que, dentro del contexto en que aparecen y según la forma en como son representados, preferimos darles este otro calificativo más acorde con lo que parecen aludir en última instancia.

La mayoría de ellos son actos onanistas, siendo indistintamente el hombre o la mujer los representados, no obstante, y aunque escasos, no falta algún que otro acto en el que se podría intuir un cunilingus, una felatio, autofelatio (fig. 10), e incluso algún acto homosexual y de defecación.

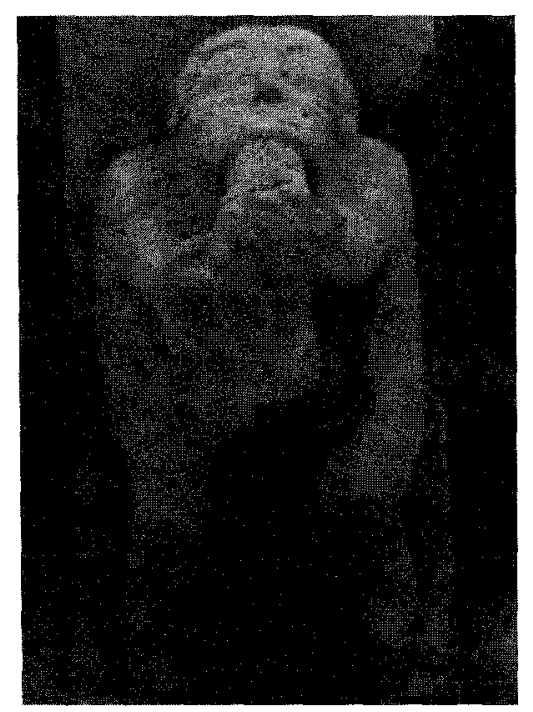

Fig. 10. San Pedro de Cervatos: Canecillo $n^{\circ}$ XVII del muro sur.

31 JaCOBELLI, M. C.: Op., cit., [pág.: 29]. 
No cabe duda que el cristianismo primitivo, ya desde los primeros momentos, combatía toda esta serie de espectáculos que formaban parte del culto, pero, no obstante, y como ya había pasado con otros aspectos, la Iglesia se veía en la necesidad no sólo de permitirlos, sino también de legalizarlos, y es así como todavía en el S. XVI son admitidas toda serie de chanzas en la iglesia con motivo de la misa de Pascua de Resurrección, y defendidas no ya por clérigos chabacanos e incultos, sino también por grandes predicadores que son igualmente teólogos y de moral intachable ${ }^{32}$.

Que durante la Misa Pascual se realizaban todo tipo de obscenidades por parte del sacerdote, nos lo confirma la carta que en 1518 envía Escolampadio a un tal Capito, y también en la que éste manda a Cándido, pues se critica al primero por no contar chascarridos, ni hacer bromas tomadas en préstamo de las cocinas, ni bromea con palabras obscenas, ni imitando a uno que se masturbe como un histrión presenta a la vista cosas que los cónyuges suelen ocultar en su dormitorio y que conviene hacer sin testigos ${ }^{33}$.

De lo dicho anteriormente se desprende que: existen suficientes datos para no dudar ya de que el elemento obsceno era inseparable del acto litúrgico, y que por lo tanto, toda esta iconografía que nosotros hemos agrupado en este apartado, cobra otra valoración.

$Y$ es que todos estos actos, en otro momento y en otro contexto muy alejado del nuestro, pero muy cercano a la vida y al mundo en el que se mueve la humanidad de nuestra plástica, lo que hacían, según Mijail Bajtin, era humillar, despachando al hombre al lugar inferior corporal absoluto, donde era destruido y engendrado de nuevo, desapareciendo luego ese sentido positivo relacionado con la tierra y el cosmos, al desvincularse del cuerpo universal al que estaban unidos en la cultura popular ${ }^{34}$. Pero en nuestra plástica, todavía la mayoría de ellos muestran una actitud un tanto solemne, al mantener la cabeza erguida, los párpados entornados y la expresión complaciente. Nada en ellos es grotesco, más bien se encuentran en postura ritual.

\section{III.7. El monstruo andrófago}

Es éste otra de las representaciones muy significativas, y que nunca falta, asociada a esta iconografía. Nos referimos aquí a esas representaciones que tienen como motivo principal a un animal, sea claramente identificable o de

\footnotetext{
32. Ibidem, [págs.: 18-19].

33 Ibídem, [págs.: 19-20]. Ver también notas 10 y 11 a pie de página.

34 Bastín, M.: Op., cit., [págs.: 25 a 31].
} 


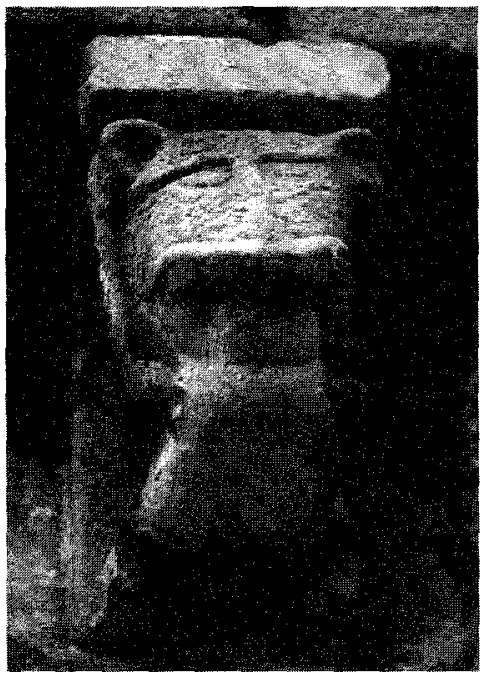

Fig. 11. Bárcena de Pie de Concha: Canecillo $n^{\circ} X I X$ del ábside.

forma monstruosa, en actitud de devorar a un ser humano. En su iconografía, aunque existen variaciones, en lo esencial, todos vienen a representar lo mismo. El ser humano engullido suele encontrarse desnudo y de rodillas (fig. 11), aunque a otros se les percibe una especie de faldelín, y con la cabeza generalmente introducida en las fauces del animal, levanta los brazos, estirados hacia arriba, enmarcando la cara del monstruo que cierra las fauces en torno a su cuello o a su cuerpo, no observándose en ellos ningún gesto de lucha o sufrimiento, más que nada parecen encontrarse en una actitud ceremonial.

Si bien los textos bíblicos aluden algunas veces a estos tipos de animales devoradores y destructores confiriéndoles un aspecto satánico, ${ }^{35}$ como pudiera ser Leviatán, e incluso apareciendo a veces como el infierno concebido como ser vivo en cuyo vientre se encuentran los condenados, ${ }^{36}$ y recogidos así en las miniaturas y en la plástica escultórica de los S. XIXII con un aspecto negativo evidente, ${ }^{37}$ no obstante, en nuestro contexto

35 Beigbeder, O.: Léxico de los símbolos. Vol. 15 de la serie Europa románica. Madrid. Ediciones Encuentro, 1989, [págs.: 295-296].

36 YARZA LuACES, J.: Formas artísticas de lo imaginario. Barcelona. Editorial Anthopos, 1987, [pág:: 173].

${ }^{37}$ Ejemplos claros los encontramos en Ibídem, [págs.: 156 a 178]. También son numerosos los ejemplos recogidos con este mismo sentido por: BEIGBEDER, O.: Op., cit., [págs.: 289 a 305 ]. E igualmente podemos verlo en algunos estudiados por: ChAMPEAux, G. y STERCKX. D.: Op., cit., [págs: 336 a 342 ] 
nada nos introduce en ese mundo infernal, muy por el contrario el ambiente que se respira es otro, por lo que nuestras representaciones están más bien en la línea de otro de esos monstruos de los que nos hablan las fuentes bíblicas, como es el pasaje de Jonás y la ballena, en el que podemos encontrar todo un mensaje de resurrección y renovación a través de la muerte simbólica, ${ }^{38}$ que es ni más ni menos que el utilizado por Jesucristo para explicar el misterio de su muerte y posterior resurrección. Siendo por tanto lo mismo que esos animales andrófagos de Manuel Guerra, como el león, el lobo, o cualquier ser monstruoso devorador, que son distintas formas de un mismo mitologema, el del animal que devora y al mismo tiempo confiere una virtualidad peculiar al hombre desaparecido en sus entrañas, capacitándolo al mismo tiempo para reaparecer en una nueva vida, ${ }^{39}$ y de ese otro andrófago de Champeaux y Sterckx, que lo hacen depender del tema imaginario del engullidor, estando en la misma cadena de símbolos que el útero que concibe y da a luz, ${ }^{40}$ del mismo modo que toda serie de leyendas, ${ }^{4}$ mitos y rituales que implican el regressus ad uterum, en donde el fin primordial de ellos es hacer que el neófito se transforme en embrión para hacerle renacer a una nueva vida ${ }^{42}$. Así pues, es ésta la imagen de un espíritu destructor y regenerador al mismo tiempo, símbolo principal en un momento decisivo como es el Año Nuevo, momento de resurgimiento en el que todo renace.

Vemos, pues, que el contexto nos está remitiendo a un concepto de renovación, y la renovación por excelencia se opera, según Mircea Eliade, en el Año Nuevo: «(...) cuando se inaugura un nuevo ciclo temporal. Pero la renovatio efectuada por el ritual del Año Nuevo es, en el fondo, una reiteración de la cosmogonía. Cada Año Nuevo recomienza la Creación. Y son los mitos - tanto cosmogónicos como mitos de origen- los que recuerdan a los hombres cómo fue creado el Mundo y todo lo que ha tenido lugar a continuación ${ }^{43}$.»

${ }_{38}^{38}$ En la Biblia de Roda vemos perfectamente ilustrado este mensaje, pues la ilustración no sólo muestra el episodio en que un enorme pez se apodera de él, sino también que aparece el citado animal en el momento que expulsa el cuerpo de éste. En: CHAMPEAUX, G. y STERCKX. D.: Op., cit., [pág.: 340].

${ }_{39}$ GUERRA, M.: Simbología románica. El cristianismo y otras religiones en el Arte Románico. Madrid. Fundación Universitaria Española, 1986, [pág.: 81].

40 Champeaux, G. y Sterckx. D.: Op., cit, [pág.: 340].

${ }^{41}$ CiRlot, J. E.: Diccionario de símbolos. Barcelona. Editorial Labor S. A. 1988, [pág.: 169].

ELIADE, M.: Mito y realidad. Barcelona. Editorial Labor S. A. 1991, [pág.: 85]. Ver del mismo autor: Imágenes y símbolos. Ensayos sobre el simbolismo mágico religioso. Madrid. Editorial Taurus, 1986, [pág.: 91]. 


\section{EL MITO Y LOS TEMAS}

No cabe duda de que en nuestro contexto, tanto por la iconografía analizada, como por las tradiciones que perviven a través del tiempo, aunque transformadas, estamos ante esto que Mircea Eliade llama la reiteración de la cosmogonía, pues, resurgen incluso algunos mitos gnósticos, más o menos enmascarados, en las literaturas orales y escritas de la Edad Media, $e$ incluso se tienen que cristianizar algunas figuras divinas y mitos paganos de las religiones populares vivas, con las que el cristianismo se encuentra en la Europa central y occidental, y que no se dejaban extirpar, ${ }^{44}$ pues cuando la tradición no oficial es rechazada, reaparece en lo que se llama la sabiduría popular, pudiendo encontrarla incluso en los rituales religiosos ${ }^{45}$. Es así como se ve sobrevivir parte de la religión popular precristiana de Europa, disfrazada o transformada, en las fiestas del calendario, y es así como ciertas categorías del pensamiento mítico se han prolongado gracias al cristianismo popular ${ }^{46}$.

Nos encontramos, pues, en un momento muy determinado, dentro del año litúrgico, en el que el hombre, a través de determinados ritos, puede pasar del tiempo profano al tiempo sagrado, pues existen estos intervalos de tiempo gracias a las fiestas que tienen lugar, la mayoría de ellas periódicas ${ }^{47}$. Y es a través de esa fiesta, en donde el pueblo reactualiza un acontecimiento sagrado que tuvo lugar en un pasado mítico, ${ }^{48}$ a través de toda una serie de rituales que originariamente se vivieron como representaciones dramáticas ${ }^{49}$.

Así pues, el primer paso que es preciso dar es el de la abolición del tiempo profano, y para abolir ese tiempo profano destructor, el hombre realiza una serie de ritos que significan una especie de fin del mundo, para encontrarse sumergido en un primer estadio que supone la regresión del Cosmos al Caos, teniendo que: el retorno de las almas de los muertos, las licencias eróticas, la confusión social del tipo de las Saturnales, las orgías,

43 ElIADE, M.: Mito y..., [pág.: 48].

44 El.ADE, M.: Mito $y . . .$, [págs.: 177 a 179].

45 Markale, J.: Druidas. (Tradiciones y dioses de los celtas). Madrid. Editorial Taurus,1989, [pág.: 35]. Para el citado autor, rastrear en el tesoro de los cuentos, de las canciones populares, de los rituales religiosos, etc., puede convertirse en una mina de información para los que buscan supervivencias, en su caso del druidismo.

46 Eliade, M.: Mito y..., [pág.: 182]. Ver también del mismo autor: Lo sagrado y lo profano. Barcelona. Guadarrama/Punto Omega. Editorial Labor,1981, [pág.: 138].

47 ElLADE, M.: Lo sagrado y..., [pág.: 63].

48 lbidem.

49 Markale, J.: Op., cit., [pág.: 141]. 
etc., simbolizaban esta regresión, y de este modo todo lo que el tiempo había mancillado y desgastado, quedaba aniquilado ${ }^{50}$.

Otros símbolos que nos hablan de este retorno al Caos, de su restauración simbólica, para volver a aquel momento de la unidad no diferenciada que precedía a la creación, serían los disfraces intersexuales y la androginia simbólica. Para Mircea Eliade, el hecho de que esta serie de disfraces se hayen extendidos durante el carnaval o en las fiestas de primavera por toda Europa, es precisamente por la principal función de este rito, como es la de salir de sí mismo para de este modo recobrar una situación original, transhumana y transhistórica, a fin de restaurar, aunque sólo sea por un momento, la plenitud inicial, la fuente intacta de la sacralidad y de la potencia, ${ }^{51}$ imagen ésta del andrógino que no podemos confundir con el hermafrodita anatómico, concreto, considerado como una aberración de la naturaleza o como un símbolo de la cólera de los dioses, que se impone a partir del S. XIX ${ }^{52}$.

$Y$ es esto precisamente lo que parece que está reactualizando toda nuestra iconografía, pues nos encontramos con un contexto muy determinado como es el de la fiesta, eminentemente religiosa, dentro del Año litúrgico, que es la que hace situar al hombre dentro de ese tiempo sagrado. A continuación el hombre de nuestro contexto emprende el retorno al caos simbolizado por esa serie de representaciones monstruosas y deformes, que representan el retorno de las almas de los muertos, así como por esas otras que se entretienen en manifestarnos toda otra serie de licencias eróticas que nos hablan de onanismo, felatio, exhibicionismo, etc., quedando así aniquilado todo lo que el tiempo había mancillado y desgastado.

Es entonces cuando ya el hombre vuelve a aquel momento de la unidad no diferenciada que precedía a la creación, a través de esa androginia simbólica (fig. 12), en donde no se representaban precisamente la acumulación de ambos sexos, sino la integración en una misma persona de los dos principios, masculino y femenino. Y es así también, como a través de estos ritos de totalización, el hombre de nuestro contexto asegura el éxito del comienzo, al final de un ciclo y principio de otro, cuando el hombre de las sociedades tradicionales repite la cosmogonía.

Una vez que el hombre ha recobrado ese estado de totalidad, se produce ya entonces el paso del Caos a la Cosmogonía, existiendo toda una serie de ceremonias muy importantes, encaminadas a la expulsión anual

\footnotetext{
50 ElIADE, M.: Lo sagrado y..., [págs.: 71-72].

51 El.Ade, M.: Mefistófeles y el Andrógino. Barcelona. Labor/Punto Omega. Editorial Labor, 1984, [págs.: 143 a 145].

52 ELIADE, M.: Mefistófeles y..., [págs.: 124 a 127].
} 


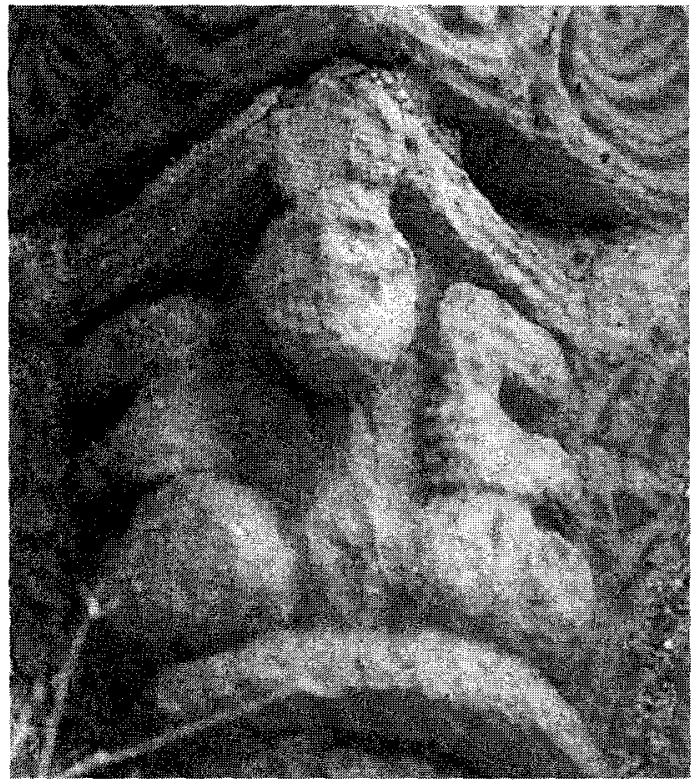

Fig. 12. San Pedro de Cervatos: Capitel derecho de la primera ventana del muro sur.

de los demonios, enfermedades y pecados, para pasar a continuación a toda una serie de rituales de los días que preceden y siguen al Año Nuevo. La expulsión de los demonios se llevaba a cabo por medio de ruidos, gritos, golpes, seguida de la persecución de aquellos. A menudo se intercalaban combates ceremoniales entre dos grupos de figurantes, $u$ orgías colectivas, o procesiones de hombres enmascarados (fig. 13) que representaban las almas de los antepasados ${ }^{53}$. Escenas de combate nos las encontramos también inmersas en nuestro contexto, siendo algunas de ellas muy significativas, pues los personajes representados muestran toda una actitud, como si de una lucha ritual se tratase. Por otro lado, toda esa otra serie de rituales serían llevados a cabo, dentro de nuestra plástica, por toda esa otra serie de enmascarados a los que se les denomina tradicionalmente, en algunas zonas de nuestra península, con el nombre de zarramaco (fig. 14), cuya función era la de producir un ruido ensordecedor, para contribuir así a la expulsión periódica de los demonios o malos espíritus.

Pero a su vez, la regeneración lleva implícito un nuevo nacimiento, por ello, después de toda esa serie de purificaciones era preciso reactualizar

53 Ellade, M.: El mito del eterno retorno. Madrid. El libro de bolsillo. Alianza Editorial 1992, [pág.: 55]. 


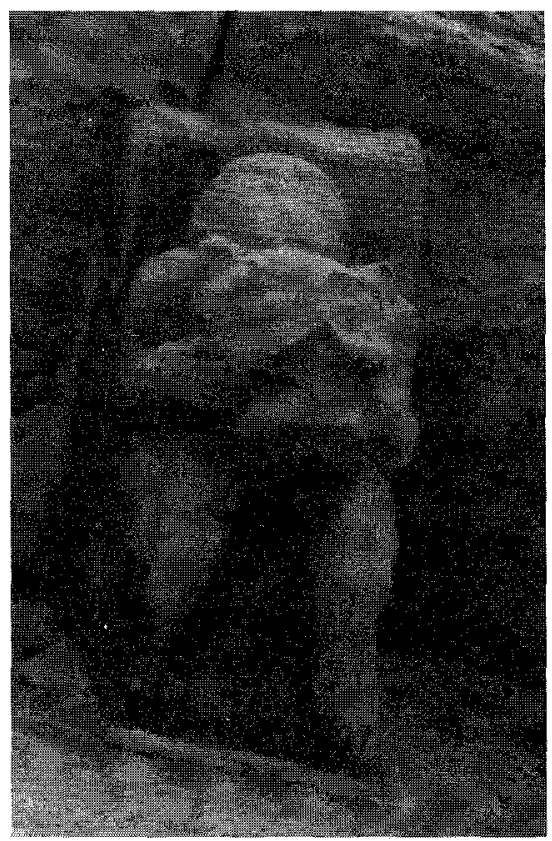

Fig. 13. San Pedro de Cervatos: Canecillo $n^{\circ} X X V /$ del ábside.

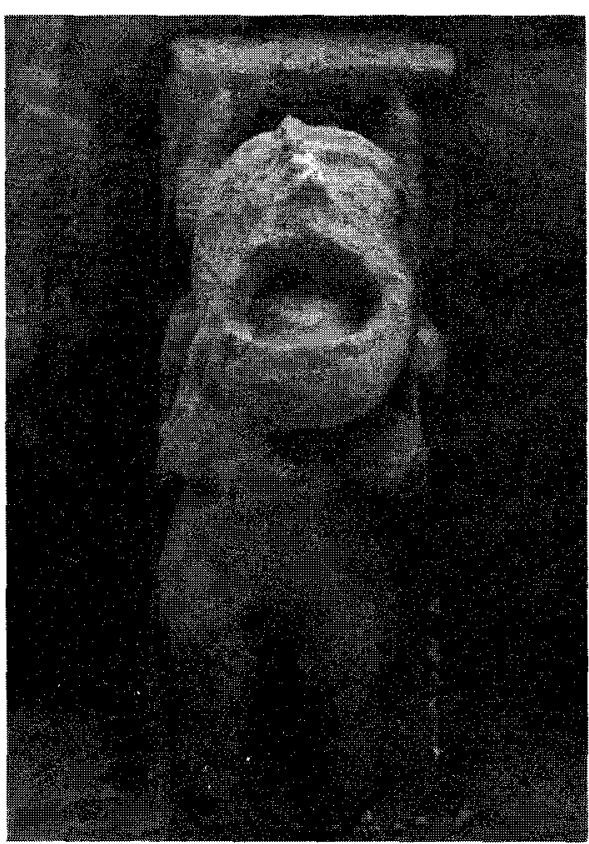

Fig. 14. San Pedro de Cervatos: Canecillo $n^{\circ}$ VIII del ábside.

la creación para propiciar el renacimiento del mundo y del hombre. No obstante, para alcanzar ese nuevo modo de existencia, para propiciar ese renacimiento, era preciso que el hombre pasase por una muerte iniciática, para así renacer a continuación ${ }^{54}$. En nuestra iconografía este simbolismo es trasmitido a través del monstruo andrófago, teniendo incluso muchas veces, como eran los mismos hombres de aquella sociedad, los que, disfrazados de forma monstruosa, reactualizaban este ritual (fig. 15).

Pero esta devoración simbólica no hace más que decirnos que lo que está preparando es un nuevo nacimiento, y para ello es preciso repetir de un modo ritual la gestación y el propio nacimiento ${ }^{55}$. De este modo asistimos al ciclo de la procreación, en el que las mujeres de nuestro contexto muestran el lugar por donde serán fecundadas por el órgano generador de su compañero, encontrándose a punto de repetir la hierogamia que tuvo lugar in illo tempore, ${ }^{56}$ y por lo que vemos también a nuestras parejas realizar el acto del coito, vien-

54 ELIADE, M.: El mito del..., [pág.: 61],

55 Eliade, M.: Mito y..., [pág.: 87]. 


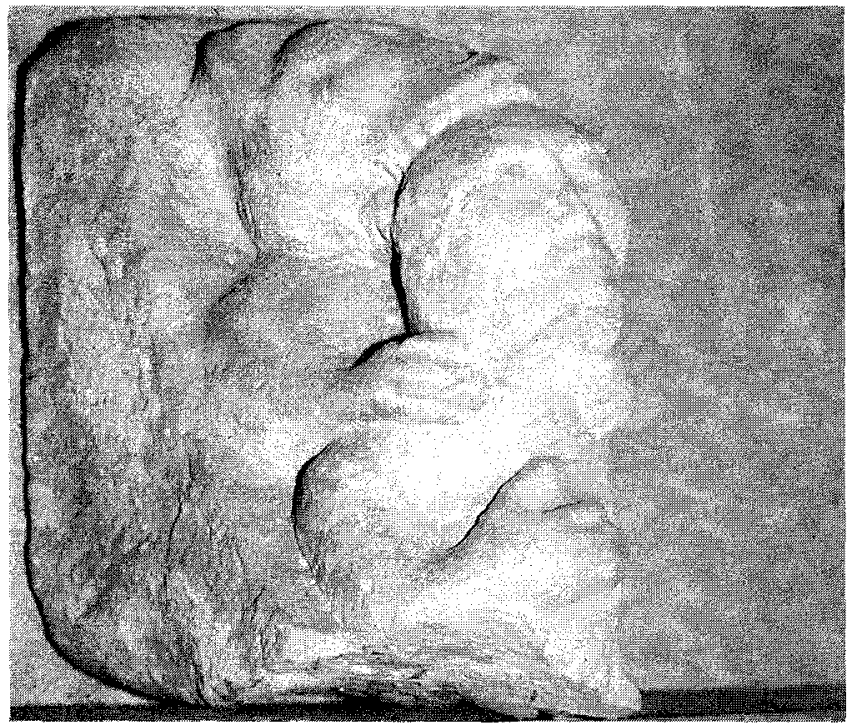

Fig. 15. Santillana del Mar: Canecillo del muro sur, actualmente en el claustro.

do continuarse este ciclo que ha comenzado, en esas mujeres en estado de gestación, y después en esos posteriores alumbramientos. Así, de este modo, los personajes de nuestra plástica están representando el comienzo y el fin de la metamorfosis, en donde ese gran cuerpo popular revela su verdadera esencia como principio en crecimiento que traspasa sus propios límites.

Después de todo lo dicho hasta aquí, ya no nos cabe duda del profundo significado que alcanza nuestra plástica, cuyas distintas iconografías alcanzan su verdadero significado gracias a la integración de todas ellas en el conjunto, por lo que estaríamos ante todo un programa iconográfico con un significado profundamente apocalíptico, y esto no es de extrañar, puesto que el marco histórico en el que se encuadra nuestra iconografía, es ni más ni menos que el de una sociedad tradicional agrícola-ganadera, apegada a su terruño, en donde ese sentimiento apocalíptico resurge en un momento muy determinado de su historia. Es por ello por lo que nuestra plástica muy bien podría estar aludiendo a esta idea, y es vivido y reiterado de una manera muy similar a como sus antepasados vivían el Año Nuevo y la Cosmogonía.

56 También para Guichot y Sierra, A.: Ciencia de la mitología. El gran mito ctónico-solar. Barcelona. Editorial Alta Fulla, 1989, [pág.: 113], existen algunas costumbres que se fundan en la creencia de que es necesaria la imitación o práctica de los actos que el mito atribuía a los dioses, con el fin de que éstos derramasen los bienes apetecidos sobre los mortales. 